\title{
Correlation of Liver Enzyme Levels and Insulin Resistance in Patients with Non-Alcoholic Steatosis
}

\section{Non-Alkolik Steatoz Hastalarında Karaciğer Enzim Düzeylerinin ve İnsülin Direncinin Korelasyonu}

\author{
Demet Cekdemir ${ }^{1}$, Mehmet Gunduz ${ }^{2}$, Arzu Celebi ${ }^{3}$, Hale Aslantas ${ }^{1}$, Gokhan Pekındıl ${ }^{4}$, Semin \\ Ayhan ${ }^{5}$, Ender Ellidokuz ${ }^{3}$ \\ ${ }^{1}$ Department of Internal Medicine, Medical Faculty, Celal Bayar University, Manisa, Turkey \\ ${ }^{2}$ Department of Hematology, Ankara Atatürk Training and Research Hospital, Ankara, Turkey \\ 3Department of Gastroenterology, Medical Faculty, Celal Bayar University, Manisa, Turkey. \\ ${ }^{4}$ Department of Radiology, Medical Faculty, Celal Bayar University, Manisa, Turkey \\ ${ }^{5}$ Department of Pathology, Medical Faculty, Celal Bayar University, Manisa, Turkey
}

\begin{abstract}
Objectives: To compare non-alcoholic steatosis patients according to liver enzyme levels, and to establish whether glucose metabolism and insulin resistance differ with liver enzyme levels.

Materials and Methods: Patients with non-alcoholic steatosis aged between 18-65 years were included in this study. The patients were divided into two groups as steatotic patients with normal liver enzymes (NLE), and those with increased liver enzymes (ILE). The groups were compared as for parameters of glucose metabolism, and insulin resistance.

Results: A total of 66 steatotic patients (40 NLE, and 26 ILE) were included in our study. Mean insulin values in the steatotic NLE, and ILE groups were $12.92 \pm 5.61$, and $16.22 \pm 5.43 \mu \mathrm{U} / \mathrm{mL}$ respectively $(\mathrm{p}=0.012)$. Insulin resistance was detected in $23(60.50 \%)$ patients in the steatotic NLE, and in $22(88 \%)$ patients in the steatotic ILE groups $(\mathrm{p}=0.018)$. Metabolic syndrome was detected in $31(77.50 \%)$ patients in the steatotic NLE, and in $15(57.70 \%)$ patients in the steatotic ILE groups ( $\mathrm{p}=0.058)$.

Conclusion: In conclusion, we have concluded that the steatotic group with ILE had higher insulin resistance. These patients should be meticulously taken into consideration as for drug treatments which will especially decrease insulin resistance, increase both weight loss, and sensitivity to insulin resistance. Liver biopsy still retains its essential place in definitive differential diagnosis.

Key words: Non-alcoholic fatty liver disease, fatty liver, insulin resistance.
\end{abstract}

\section{$\ddot{O} \mathbf{z}$}

Amaç: Non-alkolik basit hepatik steatoz hastalarını karaciğer enzim düzeylerine göre karşılaştırmak ve glikoz metabolizması ve insülin direncinin karaciğer enzim düzeyleri ile farklılık gösterip göstermediğini saptamak.

Materyal ve Metot: Çalışmaya $18-65$ yaş arası non-alkolik basit hepatik steatozu olan hastalar dahil edildi. Hastalar normal karaciğer enzimleri (NKE) ve artmıș karaciğer enzimleri (AKE) olan hastalar olarak iki gruba ayrıldı. Gruplar, glukoz metabolizması parametreleri ve insülin direnci açısından karşılaștırıldı.

Bulgular: Çalışmamıza toplam 66 steatotik hasta (40 NKE ve 26 AKE) dahil edildi. NKE ve AKE gruplarında ortalama insülin değerleri sırasıyla $12,92 \pm 5,61$ ve $16,22 \pm 5,43 \mu \mathrm{U} / \mathrm{mL}$ idi (p = o,o12). NKE'deki $23(\% 60,50)$ hastada ve steatotik AKE grubunda 22 hastada $(\% 88)$ insülin direnci saptandı $(\mathrm{p}=$ o,o18). NKE'de $31(\% 77,50)$ hastada ve AKE grubunda 15 hastada $(\% 57,70)$ metabolik sendrom saptandı (p $=0,058$ ).

Sonuç: Sonuç olarak, AKE'li steatotik grubun insülin direncinin daha yüksek olduğu sonucuna vardık. $\mathrm{Bu}$ hastalar özellikle insülin direncini azaltacak hem kilo kaybını artıracak hem de insülin direncine duyarlı olacak ilaç tedavileri konusunda titiz bir șekilde dikkate alınmalıdır. Karaciğer biyopsisi, kesin ayırıcı tanıda gerekli yerini hala korumaktadır.

Anahtar Kelimeler: Non-alkolik basit hepatik steatoz, basit hepatik steatoz, insülin direnci.

\section{Yazıșma Adresi / Correspondence:}

Dr. Demet Cekdemir

e-mail: demetcekdemir@yahoo.com.tr 
Date of submission: 17.09 .2018

Date of admission: 22.02.2019

\section{Introduction}

Non-alcoholic fatty liver disease (NAFLD) is currently the most frequent reason for the asymptomatic increase in liver enzymes, and the most frequently diagnosed liver disease. Diabetes mellitus, obesity, and hyperlipidemia lead the way among the causative factors for the development of NAFLD., Less frequently drugs, by-pass surgery, pregnancy, diseases of fat metabolism, and total parenteral nutrition may induce development of NAFLD. Nowadays, many studies have demonstrated that fatty liver disease may be a component of metabolic syndrome, and the role of insulin resistance, and inflammatory factors in the pathogenesis of NAFLD. ${ }^{1}$ When we consider the importance of insulin resistance in its etiology, the drugs which increase insulin resistance may be presumably helpful in the treatment of NAFLD. Studies which demonstrated that treatment of insulin resistance regresses the progression of NAFLD are also available. ${ }^{3}$ On the other hand, weight loss, and exercise improve metabolic state of the patient. In recent years NAFLD has become the most frequently seen liver disease with gradually increasing incidence in addition to chronic viral hepatitis, and alcoholic hepatitis in industrialized countries.4,5

Non-alcoholic fatty liver disease harbors some subgroups. In non-alcoholic steatosis, fatty liver without inflammatory infiltration is seen. In non-alcoholic steatohepatitis (NASH) together with fatty liver, as is seen in alcoholic liver disease, mega mitochondria, inflammatory infiltration, Mallory bodies, ballooning of hepatocytes, and fibrosis are seen.

In patients with non-alcoholic steatosis, adequate information about factors effecting the development of NASH is lacking. Some studies compared the patients with NASH to normal controls and demonstrated higher insulin resistance in these patients. ${ }^{6}$ Besides, a number of NASH cases can have normal liver enzyme [alanine aminotransferase (ALT) and aspartate aminotransferase (AST)] levels or on the contrary some cases with elevated liver enzymes may not have NASH. ${ }^{7}$

We aimed to compare non-alcoholic steatosis patients according to liver enzyme levels and to determine whether glucose metabolism and insulin resistance differ with liver enzyme levels.

\section{Materials and Methods}

Study design: The study has been conducted by the principles of the Helsinki Declaration and approved by the local Institutional Review Board (35/12.04.2006). Written informed consent was obtained from all subjects. This prospective study included 66 non-alcoholic steatosis patients. The patients were diagnosed with nonalcoholic steatosis by ultrasonography and computed tomography.

We aimed to compare non-alcoholic steatosis patients according to liver enzyme levels and to establish whether glucose metabolism and insulin resistance differ with liver enzyme levels. Non-alcoholic steatosis patients with normal liver enzymes (NLE) $(n=40)$ (NLE Group) and increased liver enzymes (ILE) $(n=26)$ (ILE Group) were compared. 
Exclusion criteria were as follows: pregnancy, toxic liver diseases, Wilson's disease, $\alpha-1$ antitrypsin deficiency, autoimmune liver diseases, primary sclerosing cholangitis, primary biliary cirrhosis, hemochromatosis, the presence of hepatitis B and C infection, alcohol consumption of $\geq 20 \mathrm{~g} / \mathrm{d}$.

Outcome parameters: Complete clinical, anthropometric and laboratory features of non-alcoholic steatosis cases with both high and normal liver enzyme levels were recorded.

Overweight and obesity were defined as BMI $\geq 25 \mathrm{~kg} / \mathrm{m}^{2}$ and $\geq 30 \mathrm{~kg} / \mathrm{m}^{2}$, respectively. Anthropometric parameters consisted of waist hip circumferences, waist/hip ratio, and body mass index (BMI).

The diagnosis of impaired fasting glycemia, impaired glucose intolerance (IGT) and type 2 diabetes were dependent on American Diabetes Association criteria. Resting blood pressure $\geq \mathbf{1 4 0}$ /9ommHg or being under antihypertensive drug treatment indicated hypertension. Lipid-lowering drug therapy indicated dyslipidemia.

Biochemical assessments included glucose, albumin, bilirubin, high-density lipoprotein-cholesterol, triglycerides, oral glucose tolerance test, insulin levels, ALT, AST, $\gamma$-glutamyltransferase (GGT), alkaline phosphatase (ALP).

Statistical analysis: Anthropometric, clinical and laboratory differences between groups were compared by various statistical tests. The normality of continuous data was assessed with the Shapiro-Wilk test and the variance homogeneity of the normally distributed variables were investigated with Levene's test. The normally distributed continuous variables which satisfy the variance homogeneity assumption were analyzed with independent samples t-tests. For the normally distributed variables with non-equal variances Welch t-tests were used. Non-parametric Mann Whitney U tests and Pearson's chi-square tests were used for non-normally distributed continuous and categorical variables, respectively. Continuous variables were summarized using mean \pm standard deviations or median (1st-3rd quartiles) where appropriate. Frequencies were given for categorical variables. In order to correct the p-values of each variable for multiple testing, the Benjamini-Hochberg correction was performed. Data were analyzed using the IBM Statistical Package for Social Sciences v13 (SPSS Inc., Chicago, IL, USA). $\mathrm{P}<0.05$ was considered to indicate statistical significance.

\section{Results}

A total of 66 ( 37 women, and 29 men) patients with a mean age of $48 \pm 9.0$ years and BMI of $32.0 \pm 5.1 \mathrm{~kg} / \mathrm{m}^{2}$ were included in the study. Forty $(60.60 \%)$ steatotic patients with NLE, and 26 (39.40\%) steatotic patients with ILE completed the study. Anthropometric measurements of both groups did not differ statistically significantly.

A significant difference was not detected between both groups when patients of both groups were inquired as for diseases related to insulin resistance (newly diagnosed diabetes, impaired fasting glucose, impaired glucose tolerance, and history of hypertension). History of dyslipidemia was detected in steatotic patients with NLE and ILE ( $\mathrm{n}=\mathbf{2 5} ; \mathbf{6 2 . 5 0} \%$ vs. $\mathrm{n}=7 ; \mathbf{2 6 . 9 0} \%)$ with a statistically significant intergroup difference $(\mathrm{p}=0.005)$.

The patients were also compared as for lipid parameters. Mean cholesterol (mg/dL), AST (IU/mL) and ALT (IU/mL) levels were significantly higher in ILE group $(\mathrm{p}=0.017$, 
$\mathrm{p}=0.003$, and $\mathrm{p}=0.005$; respectively). On the other hand, $\mathrm{LDL}(\mathrm{mg} / \mathrm{dL})$ values in steatotic patients with NLE was significantly higher than ILE group $(\mathrm{p}=0.026)$. Other parameters did not differ statistically significantly between groups (Table 1). A statistically significant intergroup difference was not detected as for other parameters (Table 1).

Table 1. Anthropometric, clinical and laboratory features of all cases according to liver enzyme levels.

\begin{tabular}{|c|c|c|c|}
\hline & NLE Group & ILE Group & $p$-Value \\
\hline Gender (male/female) & $18 / 22$ & $11 / 15$ & 0.882 \\
\hline Age (yr) & $50.55 \pm 7.62$ & $44.68 \pm 9.37$ & 0.071 \\
\hline $\operatorname{BMI}\left(\mathrm{kg} / \mathrm{m}^{2}\right)$ & $31.02 \pm 4.95$ & $33.74 \pm 5.06$ & 0.259 \\
\hline Waist/hip ratio & $0.97 \pm 0.06$ & $0.96 \pm 0.08$ & 0.837 \\
\hline Liver size in USG $(\mathrm{cm})$ & $163.45 \pm 17.25$ & $171.94 \pm 14.78$ & 0.295 \\
\hline Fat index & $34.8(27.6-41.4)$ & $41.4(28.2-44.5)$ & 0.440 \\
\hline Triglycerides (mg/dL) & $149(91-191)$ & $125.5(70.5-199.25)$ & 0.849 \\
\hline Cholesterol (mg/dL) & $216(204-231)$ & $183(161-208.8)$ & 0.017 \\
\hline HDL-Cholesterol (mg/dL) & $49.62 \pm 14.88$ & $47.44 \pm 16.37$ & 0.829 \\
\hline LDL-Cholesterol (mg/dL) & $135 \cdot 77 \pm 30.36$ & $108.83 \pm 33.56$ & 0.026 \\
\hline Lipoprotein (a) (mg/dL) & $14.5(7-21)$ & $12(10-31)$ & 0.847 \\
\hline Apoprotein (a) (g/L) & $1.48 \pm 0.23$ & $1.39 \pm 0.23$ & 0.391 \\
\hline Apoprotein (b) (g/L) & $1.23 \pm 1.54$ & $0.81 \pm 0.28$ & 0.261 \\
\hline AST (IU/L) & $22.38 \pm 6.26$ & $51.62 \pm 28.12$ & 0.003 \\
\hline ALT (IU/L) & $23(17-32.5)$ & $65.5(43.75-115)$ & 0.005 \\
\hline GGT (IU/L) & $21.5(15-39.25)$ & $36.5(18-73)$ & 0.185 \\
\hline ALP (IU/L) & $75.26 \pm 18.18$ & $77 \cdot 31 \pm 17.48$ & 0.812 \\
\hline Total protein $(\mathrm{g} / \mathrm{dL})$ & $7 \cdot 37 \pm 0.46$ & $7 \cdot 34 \pm 0.44$ & 0.896 \\
\hline Albumin (g/dL) & $4.21 \pm 0.30$ & $4.24 \pm 0.30$ & 0.873 \\
\hline Total bilirubin (mg/dL) & $0.65 \pm 0.21$ & $0.79 \pm 0.35$ & 0.060 \\
\hline Direct bilirubin (mg/dL) & $0.09(0.07-0.13)$ & $0.1(0.09-0.19)$ & 0.251 \\
\hline Urea $(\mathrm{mg} / \mathrm{dL})$ & $26.31 \pm 7.09$ & $27.5 \pm 8.78$ & 0.822 \\
\hline Creatinine (mg/dL) & $0.7(0.6-0.9)$ & 0.7 (0.6-0.9) & 0.911 \\
\hline Uric acid (mg/dL) & $5 \cdot 32 \pm 1.35$ & $5.43 \pm 1.55$ & 0.887 \\
\hline Ferritin $(\mu \mathrm{g} / \mathrm{dL})$ & $77(51-116.3)$ & $77(52.5-103.2)$ & 0.989 \\
\hline UIBC $(\mu \mathrm{g} / \mathrm{dL})$ & $279.14 \pm 73.58$ & $296.44 \pm 76.76$ & 0.629 \\
\hline Transferrin saturation (\%) & $19.8(6.6-46.0)$ & $30.7(11.5-52.9)$ & 0.479 \\
\hline Ferritin $(\mathrm{ng} / \mathrm{mL})$ & $50.8(22.1-87)$ & $93(39.4-184)$ & 0.258 \\
\hline $\mathrm{FT}_{3}(\mathrm{pg} / \mathrm{mL})$ & $3.16 \pm 0.45$ & $3.20 \pm 0.44$ & 0.884 \\
\hline $\mathrm{FT}_{4}(\mathrm{ng} / \mathrm{dL})$ & $1.23 \pm 0.20$ & $1.27 \pm 0.19$ & 0.693 \\
\hline $\mathrm{TSH}(\mu \mathrm{IU} / \mathrm{mL})$ & $1.73 \pm 1.32$ & $1.54 \pm 0.85$ & 0.740 \\
\hline
\end{tabular}




\begin{tabular}{|c|c|c|c|}
\hline Anti T (IU/mL) & $20(10.3-86.3)$ & $19.1(11.9-28.5)$ & 0.895 \\
\hline Anti M (IU/mL) & $9.4(5 \cdot 9-16.5)$ & $10(5-12.5)$ & 0.829 \\
\hline $\mathrm{WBC}(/ \mu \mathrm{L})$ & $7595(6877.5-8892.5)$ & $7105(6037 \cdot 5-8725)$ & 0.393 \\
\hline $\mathrm{RBC}\left({\left.\mathrm{x} 10^{6} / \mu \mathrm{L}\right)}^{6}\right.$ & $5.00 \pm 0.45$ & $4.97 \pm 0.59$ & 0.910 \\
\hline Hemoglobin (g/dL) & $14.24 \pm 1.59$ & $13.8 \pm 1.42$ & 0.536 \\
\hline Hematocrit (\%) & $43.48 \pm 3.75$ & $41.92 \pm 3.56$ & 0.291 \\
\hline Platelet $\left({\left.\mathrm{x} 10^{3} / \mu \mathrm{L}\right)}^{2}\right.$ & $264.5(224-330)$ & $238(195.5-285.5)$ & 0.241 \\
\hline $\mathrm{MCV}(\mathrm{fL})$ & $86.8(85.3-89.0)$ & $86.0(82.0-89.2)$ & 0.559 \\
\hline Lymphocyte (\%) & $32.04 \pm 7.85$ & $36.30 \pm 9.14$ & 0.240 \\
\hline Neutrophil (\%) & $56.79 \pm 8.27$ & $53.1 \pm 9.86$ & 0.282 \\
\hline $\operatorname{IgA}(\mathrm{mg} / \mathrm{dL})$ & $249(185-317)$ & $176(147-258)$ & 0.204 \\
\hline $\operatorname{IgG}(\mathrm{mg} / \mathrm{dL})$ & $1237.79 \pm 216.77$ & $1199.95 \pm 352.35$ & 0.846 \\
\hline $\operatorname{IgM}(\mathrm{mg} / \mathrm{dL})$ & $84.5(55.8-125)$ & $95\left(84 \cdot 5^{-137)}\right.$ & 0.276 \\
\hline Copper (micg/dL) & $94.9 \pm 21.74$ & $109.13 \pm 53.17$ & 0.543 \\
\hline Ceruloplasmin (mg/dl) & $24.3(22.7-28)$ & $25.05(22.8-31.3)$ & 0.623 \\
\hline Alpha-1 antitrypsin (mg/dL) & $127.09 \pm 14.63$ & $114.63 \pm 45.64$ & 0.553 \\
\hline Lactate dehydrogenase (U/L) & $177.0 \pm 37.0$ & $186.0 \pm 57.0$ & 0.647 \\
\hline Creatine kinase (U/L) & $90.5(76-127)$ & $92(69-115)$ & 0.878 \\
\hline Sedimentation (mm/hour) & $17(10-25 \cdot 5)$ & $11(6-23 \cdot 5)$ & 0.644 \\
\hline C-reactive protein $(\mathrm{mg} / \mathrm{dL})$ & $0.5(0.3-0.7)$ & $0.5(0.5-1.5)$ & 0.215 \\
\hline
\end{tabular}

NLE= Normal liver enzymes; ILE= Increased liver enzymes; USG= Ultrasonography; BMI= Body mass index; HDL= High-density lipoprotein; LDL= Low-density lipoprotein; AST= Aspartate aminotransferase; ALT = Alanine aminotransferase; GGT $=\gamma$-glutamyltransferase; ALP= Alkaline phosphatase; UIBC $=$ Unsaturated iron-binding capacity; $\mathrm{TSH}=$ Thyroid-stimulating hormone; $\mathrm{WBC}=$ White blood cell; RBC= Red blood cell; $\mathrm{MCV}=$ Mean corpuscular volume.

Data were expressed as mean \pm standard deviation or median (1st-3rd quartiles).

Independent samples t-test, Welch t-test or Mann Whitney U tests were used to compare the continuous variables across NLE and ILE groups. Pearson's chi square test is used for gender. BenjaminiHochberg procedure was performed to correct the p-values for multiple comparisons.

An $\alpha$ level of .05 was considered significant.

The patients were compared regarding hematological parameters. None of the parameters under investigation such as hemoglobin and hematocrit levels as well as platelet count $(\mathrm{x103} / \mu \mathrm{L})$ mean lymphocyte $(\%)$, and neutrophil (\%) values displayed a remarkable difference between ILE and NLE groups (Table 2). Similarly, levels of IgA (mg/dL), IgM (mg/dL) and IgG (mg/dL) were not statistically significantly different between the steatotic NLE and ILE groups. Mean levels of lactate dehydrogenase (U/L) $(\mathrm{p}=\mathrm{o} .647)$, creatine kinase $(\mathrm{U} / \mathrm{L})(\mathrm{p}=\mathrm{o.878})$, sedimentation rate $(\mathrm{mm} / \mathrm{hour})(\mathrm{p}=\mathrm{o.644})$ and C-reactive protein $(\mathrm{mg} / \mathrm{dL})(\mathrm{p}=0.215)$ were similar between 2 groups (Table 1$)$.

The patients were also compared as for parameters of glucose metabolism. Mean insulin $(\mu \mathrm{U} / \mathrm{mL})$ values in the steatotic NLE and ILE groups were 12.51 $\pm 5 \cdot 39$, and $15.41 \pm 5.78$ respectively. $P$ value was 0.059 , which indicated that there was no statistically significant difference between 2 groups. Any statistically significant intergroup difference was not detected concerning other parameters, either. The patients were also compared as for insulin resistance, and metabolic syndrome. Insulin 
resistance was detected in $23(60.50 \%)$ patients in the steatotic NLE, and in $22(88 \%)$ patients in the steatotic ILE groups, with a statistically significant intergroup difference $(\mathrm{p}=0.018)$. Metabolic syndrome was detected in $31(77.50 \%)$ patients in the steatotic NLE, and in $15(57.70 \%)$ patients in the steatotic ILE groups ( $\mathrm{p}=0.058)$ (Table 2$).$

\section{Discussion}

Insulin resistance induces increases in the severity of inflammation, and in proinflammatory cytokines with the resultant progression of liver damage to fibrosis, ad cirrhosis. ${ }^{8}$ Also, in our study, statistically significantly higher levels of insulin resistance were found in NAFLD. Nowadays, NAFLD has been started to be defined as metabolic liver disease. Though the prevalence of NAFLD is not known exactly, it has been suggested that it affects $10-39 \%$ of the world population, and its average incidence is being 20 percent. Its prevalence in the USA is estimated to range between $57-74 \%$, which makes NASH as the most frequently encountered reason of elevated liver enzymes. ${ }^{9}$

Table 2. Evaluation of patient groups as for insulin resistance, and metabolic syndrome.

\begin{tabular}{|l|c|c|c|}
\hline & NLE Group & ILE Group & $p$-Value \\
\hline Fasting glucose $(\mathrm{mg} / \mathrm{dL})$ & $111.77 \pm 19.56$ & $107.23 \pm 21.31$ & 0.377 \\
\hline PPBG $(\mathrm{mg} / \mathrm{dL})$ & $124.5(111-138.8)$ & $113.5(89.8-168.3)$ & 0.149 \\
\hline Insulin $(\mu \mathrm{U} / \mathrm{mL})$ & $12.51 \pm 5.39$ & $15.41 \pm 5.78$ & 0.059 \\
\hline OGTT-o. hour $(\mathrm{mg} / \mathrm{dL})$ & $110.27 \pm 7.48$ & $112.33 \pm 7.98$ & 0.500 \\
\hline OGTT-2. hour $(\mathrm{mg} / \mathrm{dL})$ & $117.54 \pm 44.12$ & $133.56 \pm 31.43$ & 0.332 \\
\hline HOMA & $3.47 \pm 1.65$ & $4.21 \pm 1.90$ & 0.123 \\
\hline Insulin resistance & $23(60.5 \%)$ & $\mathbf{2 2}(88 \%)$ & $\mathbf{0 . 0 1 8}$ \\
\hline Metabolic syndrome & $31(77.5 \%)$ & $15(57.7 \%)$ & 0.058 \\
\hline
\end{tabular}

PPBG= Postprandial blood glucose; OGTT= Oral glucose tolerance test; HOMA-IR= Homeostasis model assessment of insulin resistance.

Data were expressed as mean \pm standard deviation, median (1st-3rd quartiles) or $\mathrm{n}(\%)$.

Independent samples t-test, Welch t-test or Mann Whitney $U$ tests were used to compare the continuous variables across NLE and ILE groups. Pearson's chi square test was used for insulin resistance and metabolic syndrome.

An $\alpha$ level of .05 was considered significant.

Insulin resistance is not related to BMI; however, it is associated with more frequently encountered central obesity detected in individuals with NASH.

Pathogenesis of NASH retains its ambiguity. However, in many cases, it is associated with insulin resistance. Increased amounts of fatty acids presented to the liver as a result of resistance developed against the antilipolytic effect of insulin may convey importance. Besides, impaired glucose tolerance may be related to the mobilization of fatty acids. NASH has been described in $34-75 \%$ of the cases with elevated plasma glucose level. ${ }^{9}$ A tendency to a higher prevalence of NASH in type 2 diabetes patients was indicated in an autopsy study. ${ }^{9}$ Two separate large-scale studies concerning patients eligible for antiobesity surgery, Marcaeu et al. ${ }^{10}(\mathrm{n}=551)$, and Luycx et al. (11) $(n=505)$ demonstrated the close relationship between severity of NASH and impaired 
glycemic control. Haukcland et al. revealed that abnormal glucose tolerance may foresee both fibrosis and NASH. ${ }^{12}$

Since from etiological, and pathogenetic perspective insulin resistance and simple fatty liver overlap each other from many aspects, some authors have speculated that liver plays an active role in metabolic syndrome. ${ }^{13}$ Presence of insulin resistance has been demonstrated in patients with NAFLD which is more prominent in patients with NASH. ${ }^{14}$ Based on the results of National Health and Nutrition Examination Survey (NHANES-III) prevalence of NAFLD is 3-fold higher in individuals with triglyceride levels above $200 \mathrm{mg} / \mathrm{dL}$ when compared with age-, BMI-, diabetes-, and gendermatched individuals. Presence of NAFLD in individuals with increased triglyceride and very-low-density lipoprotein levels which we rather observed in metabolic syndrome is remarkable. When the importance of insulin resistance in its etiology is considered, drugs increasing insulin sensitivity in the treatment of NAFLD may be presumably beneficial. Some studies have demonstrated that treatment of insulin resistance might regress progression of NAFLD. ${ }^{3}$ In our study, when patients were compared concerning parameters of glucose metabolism, levels of insulin were higher in steatotic patients with ILE, and in this group, insulin resistance was statistically significantly higher. In literature insulin resistance has appeared to be a common pathophysiologic factor involving both in steatosis and NASH..$^{15}$ In our study as a result of higher insulin resistance detected in the steatotic ILE group, in addition to inflammation, and oxidative stress, insulin resistance is thought to be an effective factor on the development of NASH. . $^{17}$

The steatotic patients with ILE were younger than those of the other group. In the literature mean ages of the patients with similar characteristics were reported; however, we could not encounter any study which compared the ages of steatotic groups with NLE and ILE. However, mean ages of our study groups were not the ages where immune system demonstrates changes. Steatotic cases with NLE and ILE were younger than the ages where immune deviation develops. ${ }^{18,19}$ Therefore, it is not possible to comment on this issue. We thought that this was a coincidental finding.

The patients were compared for hematological parameters and no remarkable difference was detected between 2 groups. Information related to this subject has not been encountered in the literature. Our results may be considered as incidental findings. However further studies should be performed on this issue. Comparison of the peripheral levels of neutrophils, lymphocytes and other blood component may reflect the results in a limited fashion, ince these changes may occur in a different way at tissue level. Therefore, correlation of peripheral blood results with outomes of tissue analysis must be carried out to achieve more accurate results. Morepver, it must be remembered that alterations in peripheral blood levels of cells are vulnerable to be influenced by various metabolic, systemic and inflammatory conditions unrelated to the topic under investigation.

We observed that there was no difference between 2 groups in terms of IgA, IgG and IgM levels. In the literature, the correlation between serum IgA levels, and alcoholic steatosis has been demonstrated. In a study higher serum IgA levels were detected in patients with NASH relative to those with the alcoholic liver disease. In these studies, it has been indicated that gastrointestinal pathogens and/or diet rich in fat experimentally take a role in NASH, and also an increase in serum IgA levels may 
increase as a potential defense mechanism against the development of $\mathrm{NASH} .^{20}$ Besides, as is known, IL-4 and TGF- $\beta$ synergistically play roles in the pathogenesis of both steatosis and NASH. ${ }^{21}$ The reason for similarity between IgA levels in 2 groups may be related with small sample size as well as other confounding factors prone to affect Ig levels. C-reactive protein (CRP) is one of the utmost essential acute phase proteins. Inflammation is a complex process which is modulated by many cell types, and molecules. Some of these molecules initiate, reinforce, and maintain the inflammatory process, while some of them are effective in the recovery process. In clinical applications, the most prevalently used indicators of acute phase proteins are sedimentation, CRP, and albumin. The severity of acute phase response depends on the extent and activity of inflammation. TNF- $\alpha$, IL-1, and IL- 6 are effective in acute phase response. CRP and most of the acute phase proteins are effective on one or more than one phase of the inflammatory process. The major function of CRP which is a component of a natural system is its ability to induce phosphocholine, and also in addition to phospholipid components of damaged cells, it recognizes some foreign proteins. CRP interacts with both humoral, and cellular effectors of the inflammation system, and thus it may initiate elimination of target cells. Other proinflammatory effects of CRP include stimulation of inflammatory cytokines and induction of monocytic tissue factor. CRP plays a role in the pathophysiologies of inflammatory events. Higher levels of CRP in NASH group have been interpreted as the indicator of the second phase of the inflammation. . $^{-17}$

NAFLD is the most widespread liver pathology in the USA.22 According to Japanese data, the prevalence of NAFLD is 14 percent. The most important pathologies detected about NAFLD are obesity (40-100\%), type 2 diabetes, impaired glucose tolerance (20$75 \%$ ), and hyperlipidemias (20-81\%). ${ }^{23,24}$ The prevalence rates of metabolic syndrome, insulin resistance, type 2 diabetes and central obesity show parallelisms. ${ }^{25}$ In USA National Health and Nutrition Examination Survey (HHANES) study performed on 12241 individuals, the non-alcoholic liver disease was detected in $24 \%$ of all study population. ${ }^{26}$ In various case series, the prevalence of NAFLD in obese population ranges between 57.5 , and 74 percent. ${ }^{27}$ In a population without any known liver disease, $90 \%$ of abnormally increased liver enzyme levels are related to NAFLD. ${ }^{28}$ The prevalence rates of NASH are $3 \%$ in thin, $19 \%$ in obese, and $50 \%$ in morbidly obese patients. ${ }^{29,30}$ Concomitancy between diabetes and obesity demonstrates an additive effect. NAFLD carries risks of cirrhosis, and hepatocellular cancer. ${ }^{31}$ Obesity and diabetes stand as two main etiologies of NAFLD, and gradual increase in the prevalence of these diseases appears to increase also the prevalence of NAFLD. ${ }^{22}$ The main limitation of the present study is the somewhat small number of cases. Furthermore, all factors that may effect the outcomes might not be entirely documented. Due to these restrictions, associations should be interpreted with caution.

In this study, the patients with non-alcoholic steatosis were divided into two groups as steatotic patients with NLE, and ILE and the groups were compared concerning glucose metabolism and insulin resistance. As a result, we concluded that steatotic patients with ILE have higher insulin resistance. These patients should be meticulously managed concerning drug therapies aiming at especially weight-losing and increasing 
sensitivity to insulin resistance. For definitive discrimination between groups, liver biopsy still has the utmost importance.

\section{Conflict of interests}

The authors declare no conflict of interest.

\section{References}

1. Cortez-Pinto H, Camilo ME. Non-alcoholic fatty liver disease/non-alcoholic steatohepatitis (NAFLD/NASH): diagnosis and clinical course. Best Pract Res Clin Gastroenterol 2004;18:1089104.

2. Demir M, Deyneli O, Yllmaz Y. Screening for hepatic fibrosis and steatosis in Turkish patients with type 2 diabetes mellitus: A transient elastography study. Turk J Gastroenterol. 2018 Nov 9. doi: 10.5152/tjg.2018.18559. [Epub ahead of print]

3. Bugianesi E, Gentilcore E, Manini R, et al. A randomized controlled trial of metformin versus vitamin E or prescriptive diet in nonalcoholic fatty liver disease. Am J Gastroenterol 2005;100:1082-90.

4. Açikel M, Sunay S, Koplay M, Gündoğdu F, Karakelleoğlu S. Evaluation of ultrasonographic fatty liver and severity of coronary atherosclerosis, and obesity in patients undergoing coronary angiography. Anadolu Kardiyol Derg. 2009;9(4):273-9.

5. Goren B, Fen T. Non-alcoholic fatty liver disease: review. Turkiye Klinikleri J Med Sci 2005, 25:84 $1-850$.

6. Tankurt E, Biberoglu S, Ellidokuz E, et al. Hyperinsulinemia and insulin resistance in nonalcoholic steatohepatitis. J Hepatol 1999;31:963.

7. Mofrad P, Contos MJ, Haque M, et al. Clinical and histologic spectrum of nonalcoholic fatty liver disease associated with normal ALT values. Hepatology 2003;37:1286-92.

8. Neuschwander-Tetri BA. Fatty liver and the metabolic syndrome. Curr Opin Gastroenterol 2007;23:193-8.

9. Ahmed MH, Byrne CD. Nonalcoholic steatohepatitis. In: byrne CD, Wild S, eds. Metabolic Syndrome 2005:279-303.

10. Marceau P, Biron S, Hould FS, et al. Liver pathology and the metabolic syndrome X in severe obesity. J Clin Endocrinol Metab 1999;84:1513-7.

11. Luyckx FH, Desaive C, Thiry A, et al. Liver abnormalities in severely obese subjects: effect of drastic weight loss after gastroplasty. Int J Obes Relat Metab Disord 1998;22:222-6.

12. Haukeland JW, Konopski Z, Linnestad P, et al. Abnormal glucose tolerance is a predictor of steatohepatitis and fibrosis in patients with non-alcoholic fatty liver disease. Scand J Gastroenterol 2005;40:1469-77.

13. Ikai E, Ishizaki M, Suzuki Y, Ishida M, Noborizaka Y, Yamada Y. Association between hepatic steatosis, insulin resistance and hyperinsulinaemia as related to hypertension in alcohol consumers and obese people. J Hum Hypertens 1995;9:101-5.

14. Santoliquido A, Di Campli C, Miele L, et al. Hepatic steatosis and vascular disease. Eur Rev Med Pharmacol Sci 2005;9:269-71.

15. Letteron P, Fromenty B, Terris B, Degott C, Pessayre D. Acute and chronic hepatic steatosis lead to in vivo lipid peroxidation in mice. J Hepatol 1996;24:200-8.

16. Weltman MD, Farrell GC, Hall P, Ingelman-Sundberg M, Liddle C. Hepatic cytochrome P450 $2 \mathrm{E} 1$ is increased in patients with nonalcoholic steatohepatitis. Hepatology 1998;27:128-33.

17. de la Maza MP, Hirsch S, Petermann M, Suazo M, Ugarte G, Bunout D. Changes in microsomal activity in alcoholism and obesity. Alcohol Clin Exp Res 2000;24:605-10.

18. Hasler P, Zouali M. Immune receptor signaling, aging, and autoimmunity. Cell Immunol 2005;233:102-8.

19. Fulop T, Larbi A, Wikby A, Mocchegiani E, Hirokawa K, Pawelec G. Dysregulation of T-cell function in the elderly: scientific basis and clinical implications. Drugs Aging 2005;22:589-603.

20. van de Wiel A, van Hattum J, Schuurman HJ, Kater L. Immunoglobulin A in the diagnosis of alcoholic liver disease. Gastroenterology 1988;94:457-62. 
21. Kunimoto DY, Ritzel M, Tsang M. The roles of IL-4, TGF-beta and LPS in IgA switching. Eur Cytokine Netw 1992;3:407-15.

22. Malnick SD, Beergabel M, Knobler H. Non-alcoholic fatty liver: a common manifestation of a metabolic disorder. QJM 2003;96:699-709.

23. Falck-Ytter Y, Younossi ZM, Marchesini G, McCullough AJ. Clinical features and natural history of nonalcoholic steatosis syndromes. Semin Liver Dis 2001;21:17-26.

24. Kumar KS, Malet PF. Nonalcoholic steatohepatitis. Mayo Clin Proc 200o;75:733-9.

25. Farrell GC, Larter CZ. Nonalcoholic fatty liver disease: from steatosis to cirrhosis. Hepatology 2006;43:S99-S112.

26. Clark JM, Brancati FL, Diehl AM. Nonalcoholic fatty liver disease. Gastroenterology 2002;122:1649-57.

27. Daniel S, Ben-Menachem T, Vasudevan G, Ma CK, Blumenkehl M. Prospective evaluation of unexplained chronic liver transaminase abnormalities in asymptomatic and symptomatic patients. Am J Gastroenterol 1999;94:3010-4.

28. Wanless IR, Lentz JS. Fatty liver hepatitis (steatohepatitis) and obesity: an autopsy study with analysis of risk factors. Hepatology 1990;12:1106-10.

29. Silverman JF, O'Brien KF, Long S, et al. Liver pathology in morbidly obese patients with and without diabetes. Am J Gastroenterol 1990;85:1349-55.

3o. Poonawala A, Nair SP, Thuluvath PJ. Prevalence of obesity and diabetes in patients with cryptogenic cirrhosis: a case-control study. Hepatology 2000;32:689-92.

31. Non-alcoholic steatohepatitis; From cryptogenic cirrhosis to hepatocellular carcinoma. Gastroenterology 2002;123:134-40.

32. Owerweight FDA. Obesity threaten US health gains. FDA Consum 2002;36:8. 